\title{
Address by the President of the Republic of Uzbekistan H.E. Mr. Shavkat Mirziyoyev to Oliy Majlis
}

\author{
Обращение Президента Республики Узбекистан \\ Шавката Мирзиёева к Олий Мажлису
}

Allow me to deliver you the Address of the President of the Republic of Uzbekistan to Parliament on the most priority goals of Uzbekistan's development in 2019.

Today, we are living in the rapidly changing world. Global conflicts of interests and competition are growing. The international situation is being aggravated.

Accordingly, while planning practical actions for the next year, considering such harsh situation on the international arena, we need to highlight clearly and precisely the priority directions of our development.

Traditionally, with good intentions, we dedicate every year to something and set high ambitions for ourselves.

We have named the year 2018 to be "The Year of Support of Active Entreprenuership, Innovative Ideas and Technologies". Within the State Program we have implemented 76 thousand projects worth of 21 trillion soums and 1 billion US Dollars. And we are now witnessing the outcomes of actions initiated last year with good will.

The year coming to an end became the year of start of great deeds in landscaping of villages and makhallas (neighborhood areas), which represent the symbol of our sacred Homeland.

In particular, the programs "Prosperous village" and "Prosperous makhalla" have been welcomed by our people with profound joy. This year, 3 trillion soums have been allocated for construction and landscaping works within this context. 


\section{As a result, 416 villages got new image}

Thanks to open, pragmatic and active foreign policy pursued in international relations our country's international reputation to be reliable partner is increasing.

Strenghtening good-neighborly and mutually trustworthy relations with all our neighbors became one of our targets.

In 2018 we exchanged 18 official inter-state visits and signed agreements on one thousand eighty projects totaling 52 billion dollars.

The investment portfolio of partnerships with the World Bank, EBRD, IDB, $\mathrm{ADB}$ and other international finance institutions comprised 8,5 billion dollars.

Today, our country is implementing 456 projects with foreign investments worth of 23 billion dollars.

Considerig increasing threats to international and regional security, we have adopted new Defense Doctrine.

We have revised the structures and the missions of all types of troops in the Armed Forces.

To ensure the unity of the army and the people, military administrative sectors have been created in all regions.

The international experience demonstrates that those countries, which pursue active investment policy, succeed in steady growth of their economies.

It is therefore, it will not be an exageration to say that investments are driving engine of country's economy, or "it's the heart of economy" to say it in Uzbek.

Investments bring modern technologies, advanced experiences and skilled expertise to different fields and regions, facilitate development of businesses.

Here, the question arises: we say "investments", we say "reforms", we say "modernization".

But, what is the main goal of all transformations?

Our main goal is to ensure that every single individual living in our country, irrespective of ethnicity, language and religion, lives free, peaceful and wealthy life, being satisfied of today's life.

In this direction, we have great tasks ahead. Primarily, prosperity of our country and well-being of our people are closely linked with the success of our social reforms.

We need to provide worthy education to our youth, bring to reality their endeavors for education and science. In this view, we need to develop preschool education system, we must radically improve material and technical 
base of secondary and higher education institutions, the quality of education and academic process.

Certainly, we maintain as priority goal supporting and helping people with disabilities, with lost breadwinners, lone elderly, in general, all those who need help.

In the forthcoming year, we still need to do a lot to build up even more enabling business and investment environment, creating new jobs, increasing livelihoods of our population, improving pension support.

Considering all above, to make logical follow-up of activities launched in 2018 and raising it to higher level, I propose to name the New Year 2019 "The Year of Active Investment and Social Development".

We are facing following questions: how to increase investments, how to address social issues.

Every leader - whether he is a minister or the head of central authority, deputy or senator, chairman of company or association, khokim of the province or district - all of us must consider this work to be the primary mission.

We can achieve sustainable development of our economy only through active attraction of investments, launch of new production capacities.

While positive achievements in the economy will create foundation to find system solution to problems accumulated in the social field.

We need to deeply realize this and need to organize our work in this context.

Speaking about the tasks facing the sphere of economy, first of all, we need to highlight that the following goals are the core of comprehensive economic reforms:

- creating necessary conditions for open economy, sound competition, radical improvement of business and investment environment;

- increasing creation of new jobs through reduction of participation of state in the economy, intensive development of private sector;

- ensuring high economic growth through modernization and diversification of economy, increasing labor efficiency;

- countering "shadow" economy, diminishing it's share;

- consistently continuing the policy of further liberalization of exchange market, pursuing steady monetary policy;

- educating skilled human resourses capable of implementing strategic tasks related to development of economy.

To achieve these goals, it's required to implement following priority tasks. 
First, we must ensure macroeconomic stability and high growth rates of our economy.

Without prior adjustment of inflation, we cannot achieve macroeconomic stability.

Through thorough analysis of international experiences and attraction of international experts, we need to develop the concept on optimizing monetary policy and ensuring sustainable pricing.

During transition period, it is extremely important to run clear statistics of the economy and to make right assessment of economic potential of the country.

Only through this, one can achieve objective assessment of the gross domestic product.

In this view, from January 1, 2020 we need to fully introduce National accounting system of the United Nations' Organization and the International Monetary Fund.

Sustainable economic growth is primparily connected to development of leading sectors.

First of all, we will support any sector which creates products with high value added.

Therefore, we need to design and realize the Strategy on developing those industries which will give serious impact to development of the economy.

So, by April 1, 2019, the Cabinet of Ministers shall design the 2030 Concept of country's socio-economic comprehensive development and finalize its review with involvement of international experts.

We must further improve efficient use of State budget resourses.

All programs and projects to be financed from the State Budget must have quality and quantity indicators oriented to final result.

Also, within one month time, to develop the "road map" to mitigate negative impact on our economy of tendencies on global market.

We must design National Concept of Digital Economy which considers upgrade of all sectors of our economy with digital technologies. In this context, we need to introduce the Program "Uzbekistan Digital - 2030".

Digital economy will facilitate at least 30-percent increase of GDP and significant reduction of corruption. It's being also proved by the analysis of reputed international organizations.

In this regard, special attention needs to be paid at ensuring information security. 
Second, we will consistently continue active investment policy, which is the main prerequsuite of our economy's development.

In 2019, we plan to disburse investment from all sources worth of nearly 138 trillion soums, which is $16 \%$ higher versus 2018 .

In this context, the amount of foreign direct investment increased by almost 1.5 times versus this year and reached 4.2 billion dollars. As a result, we plan to launch 142 new modern enterprises.

I would like to especially outline the fact that the implemented reforms and their results are being appreciated by the world's leading credit rating agencies.

For instance, for the first time in the history, world's reputed Fitch Ratings and Standard and Poor's rating agencies identified our country's international sovereign credit rating.

The Fitch says the "Outlooks are Stable". This indicates that during next 12-18 months this indicator might be lowered.

We should note that this Uzbeistan's rating is higher compared to the most developing countries.

In the first quarter of 2019, for the first time in the history of our country, we will issue Uzbekistan's sovereign bonds to international financial markets.

In this context, we are cooperating with such leading investment banks as J.P. Morgan, City Bank and Deutsche Bank.

If we succeed to efficiently formulate the investmet projects to potential investors, we can achieve positive results.

In this view, we need to adjust allocation of business entities in free economic zones and small industrial zones, improve organizationally and legally providing them with incentives and preferences.

First of all, we need to create such environment for those businesses and foreign investors which are producing export oriented products, innovative and HiTech products.

Third, we need to actively continue the reforms in the system of banking and finances and broadly introduce the modern market mechanisms to the sphere.

Today's main problem in the banking system is that the lion's share of their capital, i.e. 83 percent belongs to the state. In its turn, this serves as an obstacle to a sober competition in the banking sector and negatively affects the quality of services.

The Government and Central Bank, along with international financial institutions, shall draft a long-term strategy on development of the banking and finances system. 
In this, through drawing private and foreign capital to banking system, we will steadily reduce the share of state banks. This will serve for improving the atmosphere of competition in the sphere, as well as comprehensively bettering the activity of commercial banks and quality of crediting services.

Besides, developing the financial markets, in particular, the stock markets should also stand as our major goals in the new economic conditions.

By way of introducing new financial instruments and issuing bonds, we need to further expand the scope of banking services and develop banking system based on cutting-edge information technologies.

For the investors to feel themselves as comfortable as possible, it is required to further liberalize the currency market.

Fourth, our citizens must be interested not to avoid taxes, but rather to paying them on time.

The main idea of the new tax concept being introduced starting from 2019 is to reduce the tax burden, apply simple and steady taxation system. Thanks to these measures we will be able to increase competitiveness of our economy and create most comfortable conditions for businesses and investors.

It is necessary to introduce the same taxation regime for all by reducing the tax burden, and removing gradually tax privileges.

Indeed, entrepreneurs themselves admit that the given privilege has a negative impact on the competitive environment.

Fifth, the efforts on supporting entrepreneurial activity will be intensified.

Our country was ranked $134^{\text {th }}$ in the World Bank's construction industry ranking.

This indicates that there are many problems in the area.

Sixth, the state intervention in the economy should be drastically reduced.

Today, there are 603 joint-stock companies in Uzbekistan, of which 486 are state-owned entities, accounting for 52 trillion soums.

The high-level state participation in the fuel and energy, petrochemical, chemical, transport, and banking sectors is hampering their development on the basis of market mechanisms and the attraction of investments.

In order to regulate the existing system, it is necessary to radically improve the activities of the State Property Management Center and reorganize it as an independent agency. 
The Agency will manage the process of privatization, financial rehabilitation through state property management, reforming of the state-owned enterprises, as well as the issuance of shares and bonds.

Seventh, in order to establish the principles of the free market, we need to create a healthy competition environment by reforming and developing leading sectors of the economy.

As a first step in this regard, we have made a decision to radically reform the system of "Uzbekenergo" and "Uzbekistan Airways" companies.

"Uzbekistan Airways" national airline was reorganized and flights, airports management and air traffic navigation services were separated.

Next year, we will continue to gradually reform other strategic sectors, including "Uzbekneftegaz", "Uzkimyosanoat", and Navoi Mining and Metallurgical Plant.

Eighth, integration of our economy into the world market and export support are among priority tasks.

Next year we are targeting to increase the exports volume by 30 percent and reach 18 billion dollars.

We need to move to an export-oriented economy, and create a competitive environment in the domestic market.

Also, the most important issue is the improvement of the transport and logistics system. Due to limited access to the sea, we are facing many difficulties in exporting our goods.

Therefore, «Uzbekistan Airways» and "Uzbekistan Railways» need to create modern logistics routes for exporting our goods.

Next year it is necessary to drastically simplify the customs procedures, radically reform customs control and cargo clearance posts.

It is necessary to build in all regions of our country the customs complexes operating on the principle of "one-stop shop» that meet the modern requirements.

Ninth, it is necessary to consistently continue the comprehensive development of the territories.

As a result of structural changes in the economy, the share of industry in GDP is expected to increase from $35 \%$ to $37 \%$ this year. However, in some cities and districts, this very important issue lacks proper attention.

In the forthcoming years, over 4 trillion soums is expected to be allocated for the implementation of the programs «Obod Qishloq" and "Obod Mahalla». 
Today, the country's urbanization rate stands at 35.5 percent, and if no action is taken now, this indicator may decline in the foreseeable future.

In this regard, it is important to focus on the comprehensive development of not only the capital and cities which make up provincial centers, but also the cities and settlements located in the regions

We should gradually move from constructing typical design houses in rural areas to building multi-storey houses in towns and settlements. Utilities and engineering infrastructure should develop in close contact with housing construction programs.

\section{The Ministry of Economy should coordinate this work}

At the same time, a special fund shall be established to perform these tasks. Funds received from privatization of land plots which accommodate the buildings and structures will be accumulated in the fund.

Through this new system we will be able to further improve the appearance of our regions and improve the wellbeing of the population.

Tenth, reforming the agricultural management system, introducing advanced technologies for the efficient use of land and water resources, and ensuring food security are our most important tasks.

In order to reach at least 52 percent of cluster cultivation of cotton, a decision has been made to create 48 cotton and textile clusters next year.

At the same time, we need to comprehensively develop the activities of grain, as well as fruit and vegetable clusters. Given that this field is relatively new to us, it requires government support, including simplification of the loan system, cost subsidization, and land allocation procedures.

In order to create genuine seed varieties, the experimental seed-breeding works must be revitalized.

To this end, it is necessary to improve the material and technical resources of seed and selective breeding institutions and to organize seed clusters on the basis of public-private partnerships.

We need to develop new crops and livestock breeding industries.

Today, only $35 \%$ of the farmers' annual feedstuff needs are covered by local means.

Therefore, we need to sharply increase the feedstuff base for livestock by expanding cultivated areas and developing new lands. Also, we need to drastically increase the volume of food products by developing fishing and poultry farming. 
Another important task is the widespread introduction of water-saving irrigation technologies.

The system of allocation of agricultural land needs to be radically revised.

It is necessary to provide multisector farmers having effectively used their land and getting sizable harvests with additional land.

The purpose of reforms in the agriculture is not only to gain economic benefit, but also ensure food security and well being of people. We must never forget this.

Ministry of Agriculture, having deeply analyzed the situation around the creation of cluster system in producing fruits and vegetables in the country, should offer proposals on lifting existing barriers by March 1, 2019.

Economic expansion and social protection are interrelated definitions, it is impossible to imagine them separately.

In 2019 - the year of "Active Investments and Social Development» we should carry out following steps towards development of social sphere.

First, we should decrease unemployment rates among population, and increase the revenues of our people and families.

In order to improve the standard of living of our people it is necessary to establish the system of proper payment and increase the real income of the population.

The minimum monthly wage should be revised, and the taxes and other payments should be reduced to the minimum wage.

The Cabinet of Ministers will develop a set of measures to address these issues within two months.

Second, it is necessary to revise the procedure for entitlement and payment of pensions and retirement benefits, fundamentally reform the pension system.

As you know, a recent presidential decree has been adopted. According to it, starting from January 1, 2019, all working pensioners will be paid full amount of pensions.

Third, it is necessary to further improve the system of science, modern and continuous education.

Therefore, we need to focus on human capital and mobilize all our effort for in this direction.

An important practical step in this direction will be reaching the coverage of the pre-school education from current 34 percent to 44 percent in 2019.

Providing our youth with the right to apply simultaneously to several 
higher education institutions, I believe, will help them expand their educational rights.

Higher education institutions need to introduce a system of independent selection of quotas based on realistic opportunities.

The opportunities for continuing education abroad for students studying for a Bachelor degree have also expanded.

Since, the more people with higher education our society has, the faster and more effective will be its development.

One of the most important issues is to further increase the scientific potential of higher education institutions, and to extend the scale of training of scientific and scientific-pedagogical cadres.

We must attract investments not only to the economic sectors of our country, but also to the areas of scientific research and "know-how".

Fourth, in order to strengthen the gene pool of our people, it is necessary to improve the quality and expand the coverage of medical services.

Our main goal is not only to treat illness, but also to prevent it.

Public-private partnerships should be expanded in the process of medical and social assistance. The scope of public health care services should be clearly defined, and a clear boundary between paid and free treatment should be established.

The next major problem is the growing population with oncological diseases.

For example, more than 22,000 patients are diagnosed with cancer in our country every year.

This, in turn, requires the need for high-tech medical care against this disease, requiring the improvement of the anti-inflammatory system.

In order to preserve the gene pool of our people, it is necessary to revise the existing norms of diet of pregnant women and children in accordance with international standards.

Fifth, social support of women and young people from the government should be further strengthened.

Despite the practical measures taken in the current year, it is sad that there are more than 13,000 women still living in difficult living conditions and are unemployed.

Within a month the Ministry of Labor and the Women's Committee, together with regional khokimiyats (governors' and mayors' offices), should develop a program providing employment for such women. 
In order to attract young people to entrepreneurship, to ensure their employment, it is necessary to further expand the "Youth is Our Future» Fund.

It is necessary to allocate more than 2 trillion sums for the Fund in 2019 and create by that more than 50 thousand new jobs.

Our most important task is to prevent our children from the influence of various radical and extreme ideas. We need to continue our work in this direction by using the new approaches.

We must take measures to create free «Wi-Fi» zones in public places and provide support to interested entrepreneurs.

Sixth, the improvement of the living conditions of the people, the provision of a decent place of residence and the raising of the well-being of people will always be at the centre of our attention.

In the coming year, the program on the construction of cheap housing will continue consistently.

A particular attention should be paid to improving the design of model houses, the use of energy-saving technologies, modern and inexpensive building materials.

At the moment, it is necessary to once again review the current condition of more than 34 thousand multi-storey buildings in our country and take practical measures on this issue.

The government must ensure that multi-storey housing stock is fully registered within three months.

Studying the experience of mega-polis cities around the world, it is necessary to develop a renovation program, meaning the construction of new houses with the modern conditions instead of outdated multi-storey buildings.

It is well-known that over the years many claims have been made to the sphere of housing and communal services.

Therefore, from 2019 we will start working in this area in cooperation with investors on the basis of public-private partnership.

Seventh, another urgent task is to establish a healthy lifestyle in the society, raise the popularity of gymnastics and sport.

We will further attach a great importance to the development of sports, encouragement and support of athletes, who have achieved high results in international competitions.

We will create children's and youth sports schools even in the remote regions in order to popularize sport among our young generation. 
We must already begin a thorough preparation for the Summer Olympics 2020 in Tokyo.

We should start developing a prospective plan for hosting one of the Asian Summer Games.

Eighth, we must take a number of measures to develop tourism, attract investment to the sector and increase the human capacity.

Especially the development of medical tourism, pilgrimage and ecotourism will not only stimulate the development of the economy, but also social spheres.

Within a month the Cabinet of Ministers should develop and implement the National Concept of Tourism Development for 2019-2025.

On this basis, it is necessary to increase the number of foreign tourists visiting our country up to 7 million by 2025, and annual income from tourism industry - up to $\$ 2$ billion.

Ninth, we need to develop a national idea that is a source of strength for us to accomplish the great tasks we face.

In particular, we need to deeply understand our own national identity, study ancient and rich history of our Homeland, strengthen the research work in this area, and support the scientists, who work in the area of humanities.

To this end, it is necessary to establish the TV Channel «History of Uzbekistan» at the National Television and Radio Company of Uzbekistan, and thoroughly produce its programs jointly with the scientific community and creative intellectuals.

It is also needed to register completely all historical exhibits in the museums in the country and create a catalog of each museum.

We all know that reform means renovation, change. In order for the reforms to succeed, first of all, our leaders and people need to change. When a person changes, society changes.

To achieve this goal, it is vital that today leaders of all levels, members of the parliament and local legislative bodies need to organize their work on the basis of critical analysis, rigorous discipline and personal responsibility.

The introduction of a modern, efficient system of governance is a key condition to fulfill the tasks set before us.

First, it is necessary to strengthen the parliament's role in adopting important decisions and its oversight functions of the implementation of laws. 
Second, it is necessary to optimize the executive power system, continue administrative reforms and apply modern management methods in public administration.

Third, in order to increase efficiency in public administration it is necessary to formulate a single personnel policy aimed at attracting qualified servants to public service.

Fourth, we need to revise the competency and responsibility of local authorities and increase their independence.

Fifth, continuous dialogue with the people, to serve the interests of the people must become not only a commitment but also a vital principle for the government officials at all levels.

In recent years, large-scale reforms aimed at ensuring the rule of law and improving the judicial system of country has been implementing.

These changes are aimed at ensuring human rights and freedom, access to justice and improving the functioning of law enforcement bodies.

First, it is necessary to further improve the system of selection and appointment of candidates for the judges in order to ensure the real independence of the judiciary.

It is necessary to fully adapt the judiciary corps formation system to the principle of independence of the judiciary and to ensure public participation in this process.

For this purpose, the selection and appointment of judges of the district, city and regional courts should be taken fully by the High Council of Judges. In this regard, public opinion and reporting in front of the people must be reflected.

Second, it is necessary to raise into a new level the ensuring the peace and security of our people and the advance prevention of crime.

This year, a lot of work has been done in this direction.

In particular, in order to create comfortable work and living conditions for the employees of the sphere, more than 6,5 thousand service homes, 1,100 private houses and 7,000 personal vehicles were provided for preventive inspectors.

At the same time, 1,800 homes will be built for the staff of National Guard.

In 2018, no offense was committed in 3,205 makhallas, and it shows the result of our correct work. But it is too early to be confident. 
We have to create in our country a climate which is fully free of crime for the sake of people to live in peace.

We need to lower the authority and functions of the Ministry of Internal Affairs to its bottom bodies and make it a true public system.

In this regard, we implement scientific approach and advanced information and communication technologies.

Each region should create its own experience of preventing and combating any crime or offense.

For the effectiveness of this work the Minister of Internal Affairs, the Commander of the National Guard and the Prosecutor General will be personally responsible for the regions of the country.

Third, it is necessary to continue the work on further improvement and liberalization of criminal legislation.

Because Criminal and Criminal Procedure Codes were adopted almost 25 years ago. In the past, relations in society, people's lifestyle, consciousness, and ideology have changed.

Therefore, these codes cannot match today's requirements.

As you know, the law contains articles on mitigating or tightening of punishment.

However, they should not be entirely dependent on the will of the investigator or the judge, i.e. the human factor.

Otherwise, the standard of justice that is holy to us will be broken.

Therefore, criminal and criminal procedure legislation must be revised.

Protecting the constitutional order, sovereignty, territorial integrity of our country from a variety of threats, and further strengthening peace and stability is the key to all our accomplishments.

In this regard the following tasks are crucial:

First of all, we need to strengthen country's defensive capabilities, the combat capability of the Armed Forces, the formation of a national defense industry, and be always ready against any threats.

The ongoing reforms to support military-economic support of the country's defense should be logically completed.

We should increase our State's border security and improve the quality of its control, using modern information and communication technologies.

We need to focus in strengthening the national spirit, upbringing of our soldiers and officers physically and spiritually in the Armed Forces. 
One of our most important tasks should be a comprehensive improvement of the emergency prevention and control system.

Second, safety of the ecology, the rational usage of water and natural resources must be in the center of our attention.

In 2019, the Ministry of Water Resources together with regional experts should develop proposals for the rational use of water resources in Central Asia.

At the present time the Aral desert has appeared in the more than 5.5 million hectares because of the Aral Sea disaster.

Every year, 100 million tons of sand and salt are being raised into the sky. This proves once again that the Aral Sea disaster is a global challenge.

The establishment of the "Trust Foundation» on the basis Multilateral Partnership for Human Security of the United Nations in the Aral Sea region has been a major achievement of Uzbek diplomacy.

We are grateful to Mr. Antonio Guterres, the Secretary-General of the United Nations, as well as United Nation's institutions and partner countries for their support of the initiative of Uzbekistan.

We are paying a special attention to the establishment of forests in the desert area of the Aral Sea.

In the Years of Independency about 1 million 220 thousand hectares of forests have been created in Uzbekistan, and from that more than 400,000 hectares have been established in the Aral Sea region.

According to the special program, another 500 thousand hectares of forests will be made in an arid area of the Aral Sea next year.

New constructions have been built in the cities and villages of the Republic of Karakalpakstan in order to improve the living conditions of the population.

In particular, in Muynak district a modern town will be constructed with the modern infrastructure.

Third, we need to continue our ongoing foreign policy based on transparency, equality and mutual beneficial cooperation, and take measures to further enhance its effectiveness.

It is necessary to establish new diplomatic missions of Uzbekistan in foreign countries, increase the number of the staff, in order to expand of the political and economic relations.

The legislative framework of the foreign economic and political activity of our state should further be improved in order to promote the political and economic interests of our country in the international arena. 
Next year, we will pursue an active foreign policy to further develop our relations with the member states of the Commonwealth of Independent States, first of all, with the Russian Federation, as well as the People's Republic of China, the United States of America, the European Union, the Republic of Korea and Japan.

We will pay special attention to further strengthen cooperation with countries of the Muslim world, which connects us with common historical, cultural and spiritual values.

We, in our foreign policy, rely on a clear and focused strategy for ensuring a security and sustainable development in Central Asia.

In this regard, Uzbekistan considers as priority task to develop practical and mutual beneficial relations with neighboring countries in the region, as well as with Turkey, India, Pakistan and Iran.

Afghanistan plays an important role in implementing this strategy.

We have urged the international community to support the need to start peace talks under the leadership of the government of the Afghanistan.

In this regard, it should be noted that the high-level Tashkent conference on Afghan issue, which was held on March 2018, was the most comprehensive international conference in new Afghanistan's history.

The "Tashkent Declaration», which was adopted by the end of the Conference, the unanimous position of all its participants, became a unique platform for peace in Afghanistan.

After that conference, international efforts to launch a negotiation process with all the political forces in Afghanistan, including the Taliban, have been intensified.

Uzbekistan has held important talks with Afghan leadership and leading political forces in the country, including the Taliban.

These political forces have acknowledged that Uzbekistan can become an effective intermediary in solving the Afghan problem.

As it is known, the key condition for stability in Afghanistan is the economic recovery of the country.

In this regard, we have begun to implement large joint projects on transport and logistics, energy, trade and education in Afghanistan.

The energy line "Surkhon-Puli Khumri» that is being constructed by Uzbekistan, the Education center in Termez city to educate Afghan citizens, logistic center "Termez-cargo" possessing its own customs station, development of railway line "Mazari Sharif-Herat» and "Mazari Sharif-Kabul-Peshawar» are the evidence of abovementioned. 
Uzbekistan always stays committed to its traditions of interethnic harmony and religious tolerance, and never goes without it.

In our country, the priority attention is given to strengthening the atmosphere of mutual respect, friendship and harmony among representatives of various ethnic and religious confessions.

As you know, recently a plenary session of the United Nations General Assembly has adopted a resolution «Enlightenment and Religious Tolerance».

The adoption of this resolution was initiated by Uzbekistan in September 2017 at the $72^{\text {nd }}$ Session of General Assembly.

It gives us great honor and pride the widely support of our proposal by 193 member-states of the United Nations, as the high appraisal and recognition by the international community of Uzbekistan's efforts,

In current stage of our country's development, every year is becoming the period of implementation of enormous programs and projects, development of our country, new achievements, knowledge and experience.

In upcoming year, we will introduce a new practice in our political life. The Prime Minister and members of the Government on quarterly basis will make reports before Senate and Legislative Chamber regarding the realization of each priority directions outlined in this Address, the main document of the forthcoming year.

We all understand one fact, it will not be easy to implement our plans and programs for 2019.

All of us have to work hard to turn these plans and programs that are still on the paper into practical work, to real results.

There is a great power that gives us confidence and inspiration, zeal and perseverance on this path, and we rely on it and rely on our goals.

This is - our people who are tempered with life tests, firm in their words, smart, hardworking, brave and courageous.

We are working hard today, trusting our people, and our youth which are our hope and future.

We are putting the great tasks in front of us considering the happiness and development of our dear children, grandchildren and bright the future of our motherland and nation.

If nation's purposes are great, its work would be great, life and future would be bright and prosperous.

We will not abandon the path of democratic reforms. No matter how difficult it may seem, we will only move forward new and high. 